\title{
Polyethism in Termites
}

\author{
Ehsan Soleymaninejadian'1, Zhongji Bao ${ }^{1}$, Shuwen Liu², Shilin Ji', Jiajia Liu' \\ ${ }^{1}$ College of Forest Resources and Environment, Institute of Forest Protection, Nanjing Forestry University, \\ Nanjing, China \\ ${ }^{2}$ The Administration Bureau of Dr. Sun Yat-sen's Mausoleum, Nanjing, China \\ Email: ${ }^{*}$ jbz9885@njfu.edu.cn
}

Received 10 April 2014; revised 25 May 2014; revised 17 June 2014

Copyright @ 2014 by authors and Scientific Research Publishing Inc.

This work is licensed under the Creative Commons Attribution International License (CC BY).

http://creativecommons.org/licenses/by/4.0/

(c) () Open Access

\begin{abstract}
Polyethism or division of works among workers of social insects is always a hot issue among entomologists. Honey bees, ants, and wasps are the main target for scientists to study the division of works. Studying polyethism in termites has been increased recently due to the damages to the forests, buildings, boats and even water preserving monuments. Every year a huge amount of money is spent to control these isopteran social insects in the south east of Asia, the US, Australia and other tropical and subtropical regions. As understanding the polyethism in these social insects can be a hand in controlling them, in this review we have tried to explain different kinds of polyethism and their importance in these social insects.
\end{abstract}

\section{Keywords}

Social Insects, Isoptera, Termite, Polyethism

\section{Introduction}

Division of task in social insect colonies is always very interesting for scientists and even politician. Bozorgmehr a Persian nobleman and scholar that served as a minister of three kings during Sassanid dynasty is one of the first trial to understand the secret of polyethism among honey bee workers. During the evolution of social insects polyethism is one of the key phenomenons [1]. Polyethism makes the colony work harmoniously. To put it in a nutshell, polyethism means division of duties among the insect colony member. As Evans revealed in his paper at 2006, in Nasutitermes exitiosus, workers shifted their work from foraging to building behavior and vice versa very rarely. This research has shown that duties are somehow divided in different individuals in a fix manner [2]. Recent studies have shown that age [3]-[7], size [8]-[11] and sex [12] or combination of them [13] are the fundamental criteria in polyethism.

\footnotetext{
"Corresponding author.
} 


\section{Age Polyethism}

Age polyethism is an eye catching area of work for entomologists because it is mostly related to foraging and nest brooding of workers. The question was that is there any relation between going out of nest and age of the workers or who are the main workers that take care of queen, king and brooding, older or younger workers. Badertscher et al. at 1982 indicate that there is a relation between age and food supply and processing in Macrotermes subhyalinus colonies. They mentioned that $97 \%$ of foragers are more than 30 days old. In addition they mentioned that the workers less than 30 years old, it does not matter they are major or minor worker, are involved in founding fungus combs [14]. In a similar study had done by Hinze et al. in 2001 signified that in Macrotermes bellicosus feeding habits are different between major and minor workers. They had classified major and minor based on their abdomen color. Furthermore, they said that foragers are the main food processor in the nest. While those worker who fed on the fungus comb have developed labial glands and their main work is to feed the queen. Abdomen color was not only considered in workers as a measuring criterion for age polyethism. It sounds that abdomen color will be changed during age in soldiers and thereafter, the duties also will be changed [15]. In M. bellicosus Smeathman three main abdomen colors have seen in soldiers, yellow, red and brown. Abdomen color will be changed from yellow in young ones to dark brown in the oldest. Brownish abdomens were the main foragers even though the soldiers with all kinds of color can be seen in the nest. Interestingly, the nest acts flexible in the time of damaging; if the brown colors were missed the reds replaced them immediately [16]. Hinze and Leuthold at 1999 demonstrate that by increasing the age of worker in M. bellicosus, their duties will be changed. They marked some known age workers with a small piece of metal and survey them by the means of photo detector. The research made it cleared that age play a crucial role in polyethism. As the age increased in the workers their duties have changed from grooming the queen to go outside the nest for foraging. In addition, age polyethism has a pivotal role on longevity of worker in social insects [7]. Mathematical model has been used to show the importance of age polyethism in longevity of workers. The analysis cleared that if aging is not depended on activity, age polyethism is profitable if the safe task done in early life, whilst if aging is depended on activity then polyethism is beneficiary if young workers do the safe works and the older workers are doing the risky works. In contrast, polyethism won't be profitable if young workers do the risky job while the old workers do the safer ones [17] [18]. In addition to workers, larvae instars also have been analyzed based on age. In Zootermopsis angusticollis, first and second instars were mainly inactive in the nest. However $64-100 \%$ of all the tasks were done by III-VII instars, but age polyethism had not seen among them. In reality, age was not the matter in division of labors and tasks were not age related [19]. In addition to Z. angusticollis, this temporal polyethism have seen in larval instars of black marching termites Hospitalitermes medioflavus [20]. In spite of all the above studies they are some studies that showed there is no relation between age and polyethism in lower termites such as Cryptotermes cavifrons [21].

\section{Size Polyethism}

Size of the termites especially workers are another important item that confirm the activity of the workers. Jones at 1980 studied the construction behavior of Nasutitermes costalis. He showed that workers with different sizes have different roles in construction behavior. He divided workers into two small workers (SW1, SW2) and three large workers (LW1, LW2, LW3) based on a research was done at 1970 by McMahan. Building behavior of all of them had been analyzed by him. He found that SW1 and LW3 are moderate in abundance at the gallery repair site, they are vigorous yet. In spite, the SW2 are the active builders. Also, LW3 are taking part in grooming [22] [23]. Recently we have showed that workers with medium head sizes are the major foraging workers in Odontotermes formosanus Shiraki [24]. As well McMahan et al. 1984 attested that 96\% of small workers are attending in queen chamber on the contrary $99 \%$ of large workers take part in foraging and $70 \%$ of them can be found around swarming sites exit holes [25]. Campora, and Grace at 2004 mentioned that the size plays a critical role in tunneling galleries. They use ANOVA and regression analysis to analyze their data. The research confirmed that large workers can make wide with less segmentation tunnels, while the small worker are good enough to make tunnels with more segmentation still less width [9]. Size polyethism is not involved only among the workers, small and large soldiers of $N$. exitiosus act differently in facing with enemies. In this species small soldiers are more attracted to the intruders and they use their frontal gland to secret and repel the invaders. In contrast, large soldiers are non combative and flee at the time of danger. Non combative large soldiers may serve as messenger and make the nest ready by raising the danger signals [26] [27]. Furthermore, one study on $N$. costalis 
has shown that soldiers have a key role in foraging by recruiting other soldiers and large workers to the source of food [28]. This phenomenon is called chemical regulation of polyethism during foraging [29]. It was cleared that large instar workers have bigger sternal glands than soldiers, subsequently produce more trail pheromone to recruit more foragers [29] [30].

Combination of age and size has seen in some of termites such as $N$. princeps. In this species, soldiers' frontal glands secret alarm signals that attract other soldiers and large older workers. The research had shown that young worker, it does not matter large or small, scarcely recruited by this alarm signal [31].

\section{Sex Polyethism}

In the case of sex polyethism, Machida et al. 2001 studied parent behaviors in Japanese dump wood Hodotermopsis japonica during preovipositional period. The research indicated that male is in charge of female grooming and feeding them by proctodeal stomodeal fluid. After eggs hatching, female used to be more in response with larvae and feeding them with trophallactic fluid [12]. In contrast with H. japonica, a research on Z. angusticollis showed lack of behavior specialization. In fact, reproductives (male and female) did different tasks and there was not seen any specialization in their duties [32]. Moreover, king in the nest has a role more than periodical insemination of the queen. In contrast with queen, king is moving around the nest with active social behavior. It may concluded that king play a key role in social structure and dynamic development of the colony as a mediator in social interaction between queen and other nest members [33]. In addition to reproductives, Miura et al. 1998 by the means of dissection and histological staining approved that in $H$. medioflavus soldiers and minor workers are male and major and medium workers are female. They said in the course of developmental pathway of neuter cast, males change their duty from gnawing (minor workers) to defense (soldiers) while females are specialized in foraging [34].

\section{Physiological Polyethism}

In addition to morphological and age changes, gene expressions, enzyme activities or other physiological character can be changed during polyethism. In these kinds of polyethism, size and morphology are not the first priorities. It means physiology is crossing age or size in a group of workers or soldiers. So, it is possible to discrete a group based on physiological competencies. As in honey bees, nurses, wax workers and soldiers are physiologically different but similar in age and size. Though, most of the time morphological changes and age have their root in physiological changes, but physiology in solo can make changes [35].

For example, in the course of soldiers, five genes that are involved in cytoskeletal structures and neuron developments were up regulated in sub esophageal ganglion (SOG): 14-3-3 epsilon, fibrillin 2, $\beta$-tubulin, ciboulot and hypothetical protein containing SAP motif [36]. Gene expression and its effects on the castes have recently studied by Tarver et al. 2010 on Reticulitermes flavipes. They mentioned that soldiers in a nest control their nest mates at the molecular level. In fact, presence of soldiers inhibits new soldiers formation in the nest by feedback regulation of genes that are involved in cast differentiation. It seems that the regulation is as a result of the terpene primer pheromones, such as Juvenile Hormone $(\mathrm{JH})$, in their heads [37]. Role of $\mathrm{JH}$ and age polyethism was cleared in honey bees long time back [38]. Also, JH has a key role in temporal polyethism in the paper wasp Polistes dominulus. In this species worker were treated with $\mathrm{JH}$ start foraging at a younger age than the ones without treatment [39]. RNA interference (RNAi) and its application in gene silencing shed light on many aspects of gene studying. Zhao and colleagues at 2006 used RNAi to prevent two hexamerin gene expressions, Hex-1 and Hex-2. These two genes are in charge of suppression of JH dependent worker differentiation into soldier caste [40]. It was not the first time that JH has a key role on gene regulation. Nijhout and Wheeler at 1982 mentioned in a paper that $\mathrm{JH}$ controled gene switching during critical periods of insect life [41].

Different cellulase enzymes activities in the guts of different workers, soldiers and larvae have been studied by Veivers et al. 1991 in Macrotermes subhyalinus and M. michaelseni Sjøstedt to find the importance of polyethism in digestion and distribution of food in the colony. They found that fungal cellulase enzyme, endo- $\beta-1,4$ glucanase, takes a part in $9 \%$ of digestion of cellulose in major worker [42]. Also, young fungal nodules have more enzyme activity and they usually consume by young minor and especially young major workers. In contrast, old major worker and old minor worker feed on old nodules with less cellulase enzymes. Interestingly, larvae and soldiers only fed by minor workers' saliva glands. This can make it clear that young workers have a key role in processing the cellulose rich material and distributing it among new born larvae [14]. 
Besides, labial glands, size, and their cellular differentiation in Schedorhinotermes lamanianus can be another physiological principle to distinguish worker-foragers from other workers. Aggregation of workers at the site of gnawing is explained by secretion of labial glands. The secretion gives a chemical signal for other workers to come to the site [43]. As well as labial glands, shape and size of mandibles have been studied in third instar workers $\left(\mathrm{W}_{3}\right)$ and forth stage reproductive nymphs $\left(\mathrm{N}_{4}\right)$ of Drepanotermes perniger Froggatt. Based on Campbell and Watson (1975) measurement and analysis the mandibles' size and shape in these two groups are different. As they mentioned in their paper, this kind of analysis will be helpful in studies of termite polyethism [44].

\section{Acknowledgements}

We thank professor Ding Yulong for his kind supports. We highly acknowledge all the professors and students in Nanjing Forestry University who helped us in this paper. This work was supported by the Specialized Research Fund for the Doctoral Program of Higher Education (grant 20123204110001) in China, the Natural Science Foundation of Jiangsu Province, China (grant BK2012816), the Priority Academic Program Development of Jiangsu Higher Education Institutions (PAPD), and the Funding Project of Nanjing Municipal Construction Bureau \& the Management Office of Dr. Sun Yat-sen’s Mausoleum (grant 200409).

\section{References}

[1] Traniello, J.F.A. and Rosengaus, R. (1997) Ecology, Evolution and Division of Labor in Social Insects. Animal Behaviour, 53, 209-213. http://dx.doi.org/10.1006/anbe.1996.0289

[2] Evans, T.A. (2006) Foraging and Building in Subterranean Termites: Task Switchers or Reserve Labourers? Insects \& Society, 53, 56-64. http://dx.doi.org/10.1007/s00040-005-0835-8

[3] Watson, J.A.L. and McMahan, E.A. (1978) Polyethism in the Australian Harvester Termite Drepanotermes (Isoptera, Termitinae). Insectes Sociaux, 1, 53-62. http://dx.doi.org/10.1007/BF02224485

[4] Gerber, C., Bardertscher, S. and Leuthold, R.H. (1988) Polyethism in Macrotermes Bellicosus (Isoptera). Insectes Sociaux, 35, 226-240. http://dx.doi.org/10.1007/BF02224056

[5] Lys, J.A. and Leuthold, R.H. (1991) Task-Specific Distribution of the Two Worker Castes in Extranidal Activities in Macrotermes bellicosus (Smeathman): Observation of Behaviour during Food Acquisition. Society Insurance, 38, 161170. http://dx.doi.org/10.1007/BF01240966

[6] Crosland, M.W.J., Lok, C.M., Wong, T.C., Shakarad, M. and Traniello, J.F.A. (1997) Division of Labor in a Lower Termite: The Majority of Tasks Are Performed by Older Workers. Animal Behaviour, 54, 999-1012. http://dx.doi.org/10.1006/anbe.1997.0509

[7] Hinze, B. and Leuthold, R.H. (1999) Age Related Polyethism and Activity Rhythms in the Nest of the Termite Macrotermes bellicosus (Isoptera, Termitidae). Insectes Sociaux, 46, 392-397. http://dx.doi.org/10.1007/s000400050162

[8] McMahan, E.A. and Watson, J.A.L. (1975) Non-Reproductive Castes and Their Development in Nasutitermes exitiosus (Hill) (Isoptera). Insecles Sociaux, 2, 183-198. http://dx.doi.org/10.1007/BF02223428

[9] Campora, C.E. and Grace, J.K. (2004) Effect of Average Worker Size on Tunneling Behavior of Formosan Subterranean Termite Colonies. Journal of Insect Behavior, 17, 777-791. http://dx.doi.org/10.1023/B:JOIR.0000048988.91950.fe

[10] Crosland, M.W.J., Ren, S.X. and Traniello, J.F.A. (1998) Division of Labor among Workers in the Termite, Reticulitennes fukienensis (Isoptera: Rhinotermitidae). Ethology, 104, 57-67. http://dx.doi.org/10.1111/j.1439-0310.1998.tb00029.x

[11] Nalepa, C.A. (2011) Body Size and Termite Evolution. Journal Evolutionary Biology, 38, 243-257. http://dx.doi.org/10.1007/s11692-011-9121-z

[12] Machida, M., Miura, T., Kitade, O. and Matsumoto, T. (2001) Sexual Polyethism of Founding Reproductives Incipient Colones of the Japanese Dump Wood Hodotermopsis japonica (Isoptera: Termopsidae). Sociobiology, 38, 501-513.

[13] Oster, G.F. and Wilson, E.O. (1978) Caste and Ecology in the Social Insects. Princeton University Press, Princeton, 352.

[14] Badertscher, S., Gerber, C. and Leuthold, R.H. (1983) Polyethism in Food Supply and Processing in Termite Colonies of Macrotermes subhyalinus (Isoptera). Behavioral Ecology and Sociobiology, 12, 115-119. http://dx.doi.org/10.1007/BF00343201

[15] Hinze, B., Crailsheim, K. and Leuthold, R.H. (2002) Polyethism in Food Processing and Social Organization in the Nest of Macrotermes bellicosus (Isoptera, Termitidae). Insectes Sociaux, 49, 31-37.

http://dx.doi.org/10.1007/s00040-002-8275-1 
[16] Konate, S., Leuthold, R., Hari, M. and Veivers, P. (2000) Color Variation and Polyethism of the Soldier Caste in the Termite Macrotermes bellicosus. Entomologia Experimentalis et Applicata, 94, 51-55. http://dx.doi.org/10.1046/j.1570-7458.2000.00603.x

[17] Tofilski, A. (2002) Influence of Age Polyethism on Longevity of Workers in Social Insects. Behavioral Ecology and Sociobiology, 51, 234-237. http://dx.doi.org/10.1007/s00265-001-0429-z

[18] Tofilski, A. (2006) Influence of Caste Polyethism on Longevity of Workers in Social Insects. Journal of Theoretical Biology, 238, 527-531. http://dx.doi.org/10.1016/j.jtbi.2005.06.008

[19] Rosengaus, R.B. and Traniello, J.F.A. (1993) Temporal Polyethism in Incipient Colonies of the Primitive Termite Zootermopsis angusticollis: A Single Multiage Caste. Journal of Insect Behavior, 6, 237-252. http://dx.doi.org/10.1007/BF01051507

[20] Miura, T. and Matsumoto, T. (1995) Worker Polymorphism and Division of in the Foraging Behavior of the Black Termite Hospitalitermes medioflavus, on Borneo Island. Naturwissenschaften, 82, 564-567.

[21] Crosland, M.W.J., Traniello, J.F.A. and Scheffrahn, R.H. (2004) Social Organization in the Drywood Termite, Cryptotermes cavifrons: Is There Polyethism among Instars? Ethology Ecology \& Evolution, 16, 117-132. http://dx.doi.org/10.1080/08927014.2004.9522641

[22] Jones, R.J. (1980) Gallery Construction by Nasutitermes costalis: Polyethism and the Behavior of Individuals. Insectes Sociaux, 27, 5-28. http://dx.doi.org/10.1007/BF02224518

[23] McMahan, E.A. (1970) Polyethism in Workers of Nasutitermes costalis (Holmgren). Insectes Sociaux, 17, $113-120$. http://dx.doi.org/10.1007/BF02223071

[24] Soleymaninejadian, E., Ji, B.Z., Liu, S.W., Yang, J.J. and Zhang, X.W. (2014) Foraging Polyethism in Odontotermes formosanus Shiraki. Journal of Advanced Agricultural Technologies, 1, 32-42.

[25] McMahan, E.A., Kumar, S. and Sarma, P.K.S. (1984) Male/Female (Size) Polyethism in Workers of Odontotermes distans Holmgren and Holmgren (Isoptera: Termitidae: Macrotermitinae). Annals of the Entomological Society of America, 77, 429-434.

[26] McMahan, E.A. (1977) Mound Repair and Foraging Polyethism in Workers of Nasutitermes exitiosus (Hill): (Isoptera: Termitidae). Insectes Sociaux, 2, 225-232. http://dx.doi.org/10.1007/BF02227173

[27] Kriston, I., Watson, J.A.L. and Eisner, T. (1977) Non-Combative Behavior of Large Soldiers of Nasutitermes exitiosus (Hill) an Analytical Study. Insectes Sociaux, 24, 103-111. http://dx.doi.org/10.1007/BF02223282

[28] Traniello, J.F.A. (1981) Enemy Deterrence in the Recruitment Strategy of a Termite: Soldier-Organized Foraging in Nasutitermes costalis. Proceedings of the National Academy of Sciences of the United States of America, 78, 19761979. http://dx.doi.org/10.1073/pnas.78.3.1976

[29] Traniello, J.F.A. and Busher, C. (1985) Chemical Regulation of Polyethism during Foraging in the Neotropical Termite Nasutitermes costalis. Journal of Chemical Ecology, 11, 319-332. http://dx.doi.org/10.1007/BF01411418

[30] Oloo, G.W. (1981) The Sternal Gland: Variation in Size and Activity in Worker Instars of Ttrinervitermes bettonianus (Sjost) (Termitidae). Insect Science and Its Application, 2, 145-147.

[31] Roisin, Y., Everaerts, C., Pasteels, J.M. and Bonnard, O. (1990) Caste-Dependent Reactions to Soldier Defensive Secretion and Chiral Alarm/Recruitment Pheromone in Nasutitermes princeps. Journal of Chemical Ecology, 16, 28652875. http://dx.doi.org/10.1007/BF00979479

[32] Rosengaus, R.B. and Traniello, J.F.A. (1991) Biparental Care in Incipient Colonies of the Dampwood Termite Zootermopsis angusticollis Hagen (Isoptera: Termopsidae). Journal of Insect Behavior, 4, 633-647. http://dx.doi.org/10.1007/BF01048075

[33] Maistrello, L. and Sbrenna, G. (1999) Behavioral Differences between Male and Female Replacement Reproductives in Kalotermes flavicollis (Isoptera, Kalotermitidae). Insectes Sociaux, 46, 186-191. http://dx.doi.org/10.1007/s000400050131

[34] Miura, T., Roisin, Y. and Matsumoto, T. (1998) Developmental Pathway and Polyethism of Neuter Castes in the Processional Nasutetermite Hospitalitermes medioflavus (Isoptera: Termitidae). Zoological Science, 15, 843-848. http://dx.doi.org/10.1007/s000400050131

[35] Robinson, E.J.H. (2009) Physiology as a Caste-Defining Feature. Insectes Sociaux, 56, 1-6. http://dx.doi.org/10.1007/s00040-008-1035-0

[36] Ishikawa, Y., Okada, Y., Ishikawa, A., Miyakawa, H., Koshikawa, S. and Miura, T. (2010) Gene Expression Changes during Caste-Specific Neuronal Development in the Damp-Wood Termite Hodotermopsis sjostedti. BMC Genomics, 11, 314. http://dx.doi.org/10.1186/1471-2164-11-314

[37] Tarver, M.R., Zhou, X. and Scharf, M.E. (2010) Socio-Environmental and Endocrine Influences on Developmental and Caste-Regulatory Gene Expression in the Eusocial Termite Reticulitermes flavipes. BMC Molecular Biology, 11, 28. 
http://dx.doi.org/10.1186/1471-2199-11-28

[38] Robinson, G.E. (1987) Regulation of Honey Bee Age Polyethism by Juvenile Hormone. Behavioral Ecology and Sociobiology, 20, 329-338. http://dx.doi.org/10.1007/BF00300679

[39] Shorter, J.H. and Tibbetts, E.A. (2009) The Effect of Juvenile Hormone on Temporal Polyethism in the Paper Wasp Polistes dominulus. Insectes Sociaux, 56, 7-13.

[40] Zhou, X., Oi, F.M. and Scharf, M.E. (2006) Social Exploitation of Hexamerin: RNAi Reveals a Major Caste-Regulatory Factor in Termites. Proceedings of the National Academy of Sciences of the United States of America, 12, 44994504. http://dx.doi.org/10.1073/pnas.0508866103

[41] Nijhout, H.F. and Wheeler, D.E. (1982) Juvenile Hormone and the Physiological Basis of Insect Polymorphisms. The Quarterly Review of Biology, 57, 109-133. http://dx.doi.org/10.1086/412671

[42] Veivers, P.C., Hlemann, R.M., Slaytor, M., Leuthold, R.H. and Bignell, D.E. (1991) Digestion, Diet and Polyethism in Two Fungus-Growing Termites: In Macrotermes subhyalinus and M. michaelseni Sjøstedt. Journal of Insect Physiology, 37, 675-682. http://dx.doi.org/10.1016/0022-1910(91)90044-Z

[43] Kaib, M. and Ziesmann, J. (1992) The Labial Gland in the Termite Schedorhinotermes lamanianus (Isoptera: Rhinotermitidae): Morphology and Function during Communal Food Exploitation. Insectes Sociaux, 39, 373-384. http://dx.doi.org/10.1007/BF01240622

[44] Campbell, N.A. and Watson, J.A.L. (1975) A Multivariate Study of Mandibular Characters in Fifth Instar Workers and Nymphs of Drepanotermes perniger (Froggatt) (Isoptera: Termitinae). Insectes Sociaux, 22, 293-306. http://dx.doi.org/10.1007/BF02223078 
Scientific Research Publishing (SCIRP) is one of the largest Open Access journal publishers. It is currently publishing more than 200 open access, online, peer-reviewed journals covering a wide range of academic disciplines. SCIRP serves the worldwide academic communities and contributes to the progress and application of science with its publication.

Other selected journals from SCIRP are listed as below. Submit your manuscript to us via either submit@scirp.org or Online Submission Portal.
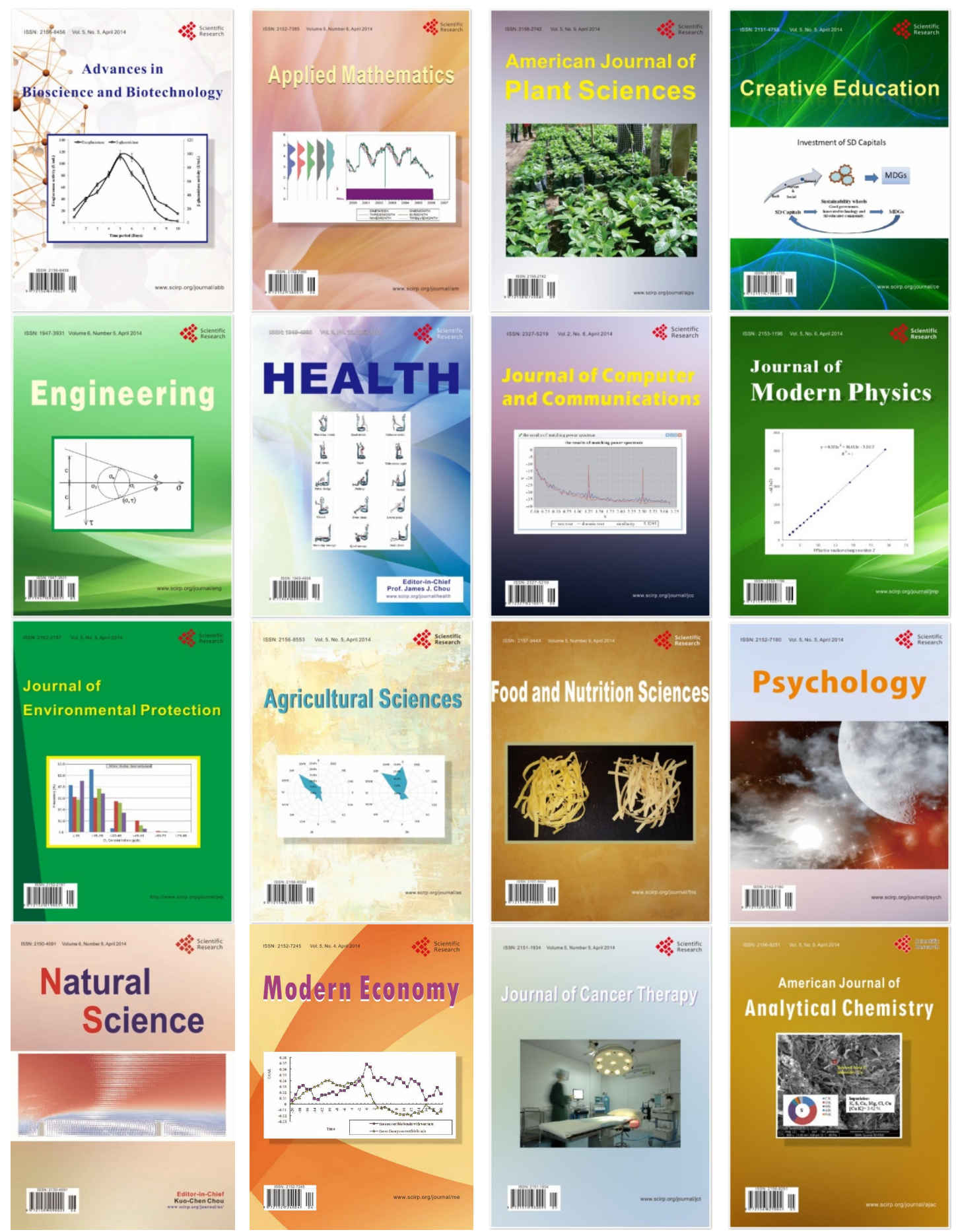